\title{
BENCH V BAR: CONTEMPT OF COURT AND THE NEW ZEALAND LEGAL PROFESSION IN GILLON V MACDONALD (1878)
}

\author{
Grant Morris*
}

\begin{abstract}
Gillon v MacDonald (1878) was the climax of a feud that caused division in, and undermined the reputation of, the early New Zealand legal profession. Gillon features one of the most controversial episodes of contempt of court by a barrister in colonial legal history. The nature of the New Zealand legal profession, and in particular the relationship between bench and bar, is exposed through the case, its prologue and its aftermath. The complex saga occurred over several years and involved all three branches of government. Its causes are open to debate, but this article argues that personal and professional rivalry lies at the heart of the saga, and in particular, an obsessive vendetta on the part of George Elliot Barton. The events described in this article had far reaching consequences including possibly influencing New Zealand's most infamous legal decision, Wi Parata v Bishop of Wellington (1877).
\end{abstract}

\section{INTRODUCTION}

When looking at the Wellington Supreme Court Bench in the late 1870s, legal historians invariably focus on the landmark case of Wi Parata $v$ Bishop of Wellington (1877). ${ }^{1}$ This case provided infamous decisions on the issues of native title and the place of the Treaty of Waitangi in New Zealand's legal system. Chief Justice James Prendergast and Justice Christopher William Richmond handed down the decision in Wi Parata. ${ }^{2}$ George E Barton represented Wi Parata while William Travers represented the Bishop of Wellington. Yet it was not this case that dominated headlines during the period. It was another, featuring a remarkably similar cast.

* Senior Lecturer in Law, Victoria University of Wellington.

1 Wi Parata v Bishop of Wellington (1877) 3 NZ Jur (NS) 72 (SC).

2 Recent research by the New Zealand Lost Cases Project has revealed that although Prendergast and Richmond both presided over the case, Richmond's judicial notes contain the draft decision despite the fact that Prendergast delivered the decision in court. 
On 30 January 1878, Gillon v MacDonald was heard before the Wellington Supreme Court. ${ }^{3}$ The case concerned a commercial partnership issue but should be considered a leading case due to Barton being held in contempt of court and imprisoned for one month by the Chief Justice. This incident was the climax of many months of feuding between the two Wellington judges and Barton. The feud was primarily between Barton and Prendergast up until the final months when Barton focused more on attacking Richmond. The Chief Justice had a longer association with Barton and also made the finding of contempt, therefore this article will focus more on Prendergast than Richmond.

The unprecedented nature of Barton's punishment made Gillon the cause celebre of the year and split the New Zealand legal profession. The feuding did not end with Barton's imprisonment but instead became more intense and bizarre as the year continued. The matter finally dissipated at the end of 1878 though not before it had destroyed the careers of Barton and his client Gillon, and seriously undermined the early years of Prendergast's Chief Justiceship. It is also arguable that the feud had some effect on the 'other' leading case of this period, namely, Wi Parata.

There are many ways in which the legal historian can approach the Gillon case and the Wellington Supreme Court feud. This article investigates what these events can tell us about the nature of the New Zealand legal profession during the late 1870s. The multifarious aspects of this story touch on the relationship between bench and bar, the relationship between fellow lawyers, the operation of the separation of powers doctrine in colonial New Zealand, contempt of court and the removal of judges. Several articles could be written on these important issues and it is unrealistic to attempt to do justice to all the issues in one article thus the focus on the nature of the legal profession. Whichever way it is approached, the Gillon saga is quite simply one of the most fascinating stories in New Zealand's legal history but it is one that has largely been 'lost'.

\section{THE GILLON SAGA}

\section{A The Events Leading up to Gillon}

In the late 1870s, the New Zealand legal profession included many men who had previously sought their fortunes in other colonial contexts. Therefore, it is not too surprising that the Englishman James Prendergast and the Irishman George E Barton had 'history'. Two previous goldrushes had brought the men together, first in Victoria and then in Otago. After leaving legal practice in Dublin for the Victorian goldfields during the 1850s, Barton was a political associate of Michael

3 Gillon v MacDonald (1878) 3 NZ Jur (NS) 27 (SC). Much of the reporting of the events in question appears in The New Zealand Jurist which served as both a legal magazine and a law report series during the 1870s. 
Prendergast, James' elder brother. ${ }^{4}$ Barton and Michael Prendergast served in Victoria's Legislative Assembly and in 1860 they conducted a political tour of the mining districts together. ${ }^{5}$

During the early 1860s, James Prendergast, Michael Prendergast and Barton migrated separately to Dunedin as news spread of a major gold rush. They were part of a third wave of colonists following gold, the first wave being in California, the second in Victoria, and the third in Otago. Other prominent New Zealanders also arrived as part of this massive movement of men, including future premier, Julius Vogel. When the gold rush began to subside many in Dunedin's legal profession moved north to the newly established capital of Wellington; Barton, Prendergast and Christopher William Richmond among them. ${ }^{6}$ Barton's personal relationship with Richmond before 1876 is unclear. A professional relationship definitely existed. Richmond began his judicial career in Dunedin in 1862, the year Barton commenced practice in the same city. In 1867 Richmond left for Nelson meaning that for five years Barton would have advocated in the court over which Richmond presided.

One of Prendergast's most well-known performances as a lawyer in Dunedin involved arguing against Julius Vogel. In 1864 the Otago Daily Times was facing a libel charge brought by the New Zealand Banking Corporation. Prendergast represented the plaintiff and was aided by Barton. Vogel was editor of the Otago Daily Times and implicated in the charge. The jury awarded damages of 500 pounds, much less than was sought by the plaintiff, but still a victory for Prendergast's client. ${ }^{7}$ While in Dunedin, Prendergast and Barton appeared in other cases together and also appeared against each other. ${ }^{8}$ By all accounts, the two men were on civil terms up until their third meeting in Wellington during the late 1870 s. $^{9}$ This also appears to be the case with Richmond and Barton.

4 There is no direct evidence that James Prendergast knew Barton in Victoria but given that both men were working in the same geographical area and the strong relationship between Michael Prendergast and Barton it is highly likely that James had some acquaintance with Barton at that time.

5 The Argus (Victoria, Australia, 17 April 1860) at 4.

6 Grant Morris "Chief Justice James Prendergast and the Administration of Colonial Justice, 1862-1899" (PhD Thesis, University of Waikato, 2001) at ch 4.

7 Case details appear in the Hawkes Bay Herald (Napier, 8 November 1864) at 2 and the Otago Witness (Dunedin, 5 November 1864) at 11 and (12 November 1864) at 7. The case is also referred to in Iain Gallaway "Otago" in Robin Cooke (ed) Portrait of a Profession: The Centennial Book of the New Zealand Law Society (Reed, Wellington, 1969) 330 at 331.

8 See Morris, above n 6, at 54 .

9 In relation to the first contempt charge in 1876 Barton uses the phrase "former friendship" in relation to Prendergast, Re GE Barton (1876) 2 NZ Jur (NS) 13 (SC) at 14. Barton also states "Although I cannot forget that I am addressing a gentleman who for years practised with me at the Dunedin bar, and who until I came to reside permanently in Wellington was on terms of friendship with me, yet I will study to remember that I am addressing the Chief Justice of New Zealand" in Re GE Barton (1876) 1 NZ Jur (NS) 109 (SC) at 110 (earlier hearing). 
However, it is worth noting that Prendergast's early personal correspondence reveals anti-Irish sentiment and George E Barton was an Irish Protestant. Much of the sentiment is second-hand and appears in letters from his brothers, Philip and Michael junior, to their father, Michael Prendergast QC. ${ }^{10}$ James' brothers argued that Irish Protestants should be blamed for his failure to establish himself in Victoria. For example, while in Victoria, Michael wrote to his father in London: ${ }^{11}$

By this time you will have heard from James that his removal from the Government service is solely attributable to the malice and jobbery of the detestable Irish Orange set that are the curse of the Colony.

Philip and Michael were scathing about the Irish Protestants in power in Victoria during the 1850s. This prejudice could have some bearing on the Gillon saga although it is very difficult to ascertain whether there is a link between the Prendergast-Barton feud and James Prendergast's negative experiences with Irish Protestants in Victoria.

The Wellington legal profession which Barton joined in the late 1870s was thriving. Government and commercial interests provided a plentiful supply of work for the small group of lawyers working in New Zealand's new capital city. It is no surprise that when the New Zealand Law Society was established in 1869 Wellington lawyers dominated the organisation. The Wellington legal profession consisted of long-established lawyers whose Wellington careers had preceded the relocation of the capital, and more recent arrivals, such as Barton.

The 15 August 1877 address made by 14 leading Wellington barristers in support of Prendergast and Richmond reads as a 'Who's Who' of the Wellington legal fraternity. The lawyers in attendance were Chapman, Edwards, FitzGerald, Fitzherbert, Allan, Izard, Lewis, Moorhouse, Ollivier, Quick, Travers, Hart, Brandon and Brandon junior. ${ }^{12}$ These men were at the centre of the Wellington legal profession and had little time for those like Barton who sought to challenge the establishment. Martin Chapman was a founder of Chapman Tripp; Worley Bassett Edwards became a controversial Supreme Court judge; William Fitzgerald (along with Martin Chapman) was the New Zealand Jurist's court reporter for Wellington; Charles Izard established the firm that would become Bell Gully; Brandon senior, Moorhouse and Travers were all members of the House of Representatives which would debate Barton's petitions while Brandon senior and Robert Hart were responsible for establishing Wellington's earliest law firms in the 1840s. ${ }^{13}$ Other leading Wellington lawyers at the

10 James' references to the Irish in Victoria are more oblique, for example, he mentions a "mean little Irish Barrister appointed Police Magistrate and altogether unfit for his place." James Prendergast, "Letter sent from Melbourne to his father in London", Alexander Turnbull Library, Wellington, MS-Papers 1791, 28 October 1854.

11 Michael Prendergast "Letter sent from Melbourne to his father in London", Alexander Turnbull Library, Wellington, MS-Papers 1791, 17 May 1855.

12 "Mr GE Barton's Petition" (1877) 2 NZ Jur (NS) 163 at 166.

13 Robin Cooke "Wellington" in Cooke (ed), above n 7, 388 at 395. 
time not present on 15 August included Henry Dillon Bell, Hugh Gully and Walter Buller. Interestingly, Fitzherbert was Barton's partner at the time in the firm of Barton and Fitzherbert.

Dunedin in the 1860 s is seen by many legal historians as the first 'golden age' of the New Zealand legal profession due to the strength of the local bar. As seen by the list of practitioners above, Wellington in the late 1870s has a strong claim to be seen as the second 'golden age' using the same measure. The profession was small but impressive. The public and private relationships between practitioners were complex and sometimes compromising. For example in the Gillon feud, William Travers appeared for the plaintiff in court, publicly supported the judges at the 15 August meeting and spoke on their behalf in parliamentary debates. Like the Supreme Court judges, Travers found himself in constant conflict with Barton from 1876 to 1878.

Barton left New Zealand under a cloud of controversy in the 1870s only to return to practice in Wellington a few years later in $1876 .{ }^{14}$ The controversy apparently concerned an action for slander against Barton for accusing another lawyer of stealing a document. Barton was found liable and immediately left New Zealand. ${ }^{15}$ In 1875 Prendergast was appointed Chief Justice, after having served as Attorney-General for 10 years. ${ }^{16}$ When Barton arrived in Wellington in 1876 it was very clear to him that his former colleague had far outstripped him in terms of career success. ${ }^{17}$ Both men were of similar age and backgrounds yet by 1875 Barton had failed to receive the recognition that a man of his experience might have expected, especially in a small legal community such as that of colonial New Zealand. In Robert Stout's eulogy to Prendergast in 1921, he describes Barton as "a brilliant advocate" when referring to the 'golden age' of the New Zealand legal profession in Dunedin during the 1860 s and early 1870 s. ${ }^{18}$ To paraphrase Oliver Wendell Holmes' famous assessment of Franklin Delano Roosevelt, Barton had a first rate intellect but a third rate temperament.

Barton had a very hot temper and throughout his career was in a state of almost constant feuding with a myriad of different individuals. His confrontational personality, possibly augmented by jealously, resulted in a stand-off with Prendergast very soon after Barton began appearing before the

14 Barton's movements between 1874 and 1876 are unclear.

15 "Brief Biography of George E Barton", Alexander Turnbull Library (ATL), Wellington, MS-Papers-0212C/04 (Guy Scholefield's letters relating to the Dictionary of New Zealand Biography). There is no stated author for this document but it appears to be written by one of Barton's sons for the purposes of the dictionary.

16 Grant Morris "James Prendergast and the New Zealand Parliament: Issues in the Legislative Council during the 1860s" (2005) 3 NZJPIL 177 at 177-178.

17 During Re GE Barton (1876) 1 NZ Jur (NS) 109 at 110, Barton states "whatever my fate is likely to be, no word shall escape my lips unworthy of my standing at this bar; my age, which exceeds your Honour's; my seniority at the bar - of 27 years - which also exceeds your Honour's."

18 New Zealand Times (Wellington, 4 March 1921). 
judge in the Wellington Supreme Court. In October 1876 Barton took offence at Prendergast's remarks during the trial of Te Puni. ${ }^{19}$ According to Barton, both Wellington judges, Prendergast and Richmond, had been disrespectful towards him and the comments in this case were the final straw. Barton penned a letter to the Colonial Secretary requesting an inquiry into the judges' behaviour. ${ }^{20}$ He also informed Prendergast of this course of action via a letter. By writing the letters, Barton had made conflict inevitable. Bench and bar would clash and Prendergast's rash response confirmed this. Prendergast held Barton in contempt of court for sending him the letter, the first of three times Prendergast charged Barton with this serious, strict liability offence.

In the subsequent hearing, Re GE Barton, Barton argued as to why the contempt charge was unjustified. ${ }^{21}$ Barton's demeanour was almost humble as he outlined why he had sent the letter and how he had not meant any offence by it. While this may have appeared disingenuous given the gravity of Barton's allegations, Prendergast retracted his decision and the first contempt ruling was discharged. 22

The Colonial Secretary did not act on Barton's request for an inquiry. Despite the apparent truce in Re GE Barton, the feud between bench and bar intensified during 1877. In case after case, Barton found reasons to be aggrieved at the treatment he received from Prendergast and Richmond. ${ }^{23}$ In August 1877, Barton once again attempted to take official action against the judges. Breaking ranks with the profession, he directly petitioned the House of Representatives, asking for an inquiry into the judges' behaviour. ${ }^{24}$ Under the New Zealand constitution, past and present, only the House of Representatives can remove judges of the higher courts. ${ }^{25}$ Barton accused the judges of treating him

19 "Supreme Court This Day" Evening Post (Wellington, 10 October 1876) at 2. Barton refers to the defendant as Jacob Pune.

$20 \operatorname{Re}$ GE Barton (1876) 2 NZ Jur (NS) 13 (SC) at 13-14.

21 Ibid, at 13.

22 Ibid, at 17-18.

23 The key cases cited by Barton are; Corporation of Wellington v CW Schultze, Gillon v MacDonald, Peters v Joseph, Pole v Tonks, Leach v Johnston, Doherty v Education Board, and Buckridge v Wardell: $\mathrm{Mr}$ Barton's Charges Against Judges of the Supreme Court" [1879] AJHR A4 at 2. Details of all the cases are included in the AJHR document while reported judgments can be found for some of the cases: Gillon $v$ MacDonald (1878) 3 NZ Jur (NS) 27 (SC); Peters v Joseph (1878) 3 NZ Jur (NS) 142; Pole v Tonks (reported as Poll, ex parte, in re Tonks) (1877) 3 NZ Jur (NS) 1; Doherty v Education Board (1878) 4 NZ Jur (NS) 78.

24 "Petition from Barton to the Colonial Secretary, 22 August 1877" Archives New Zealand, Wellington, [ANZ] J1 1877/3334; "Mr GE Barton's Petition" (1877) 2 NZ Jur (NS) 163.

25 This principle is now enshrined in the Constitution Act 1986, ss 23-24. The 1986 Act stipulates that dismissal can only occur on grounds of misbehaviour or incapacity. This Act repealed s 7 of the Judicature Act 1908 which used the term "good behaviour". The process for dismissal is instigated by the executive and in our present system by the Attorney-General (Judicial Conduct Commissioner and Judicial Conduct Panel Act 2004). The House of Representatives makes the final decision but has never dismissed a judge in 
in a disrespectful manner, undermining his reputation, showing bias towards his clients and directly insulting him.

It is at this point in the story that a harmful split in the Wellington legal profession becomes evident. Legal news in August 1877 was dominated by the scandal of Barton's attack on the judges ${ }^{26}$ yet these very judges were also hearing a case involving a parcel of Ngati Toa land. This case was Wi Parata v Bishop of Wellington and is the most infamous case in New Zealand's legal history. ${ }^{27}$ It says much about the priorities of the colonial legal establishment that the fates of the native title doctrine and the Treaty of Waitangi were put on hold so that leaders of the Wellington bar could read out a statement in the Supreme Court supporting Prendergast and Richmond. ${ }^{28}$ Barton claimed that the statement reflected "the cringing servility of the Wellington local bar". ${ }^{29}$ Given that Barton was representing the plaintiff in the case before the court, we can only guess at the reaction of Wi Parata, rangatira of Ngati Toa. With so much at stake for Maori, the lawyer charged with defending Maori interests was in effect publicly branded a pariah by the overwhelming majority of his local colleagues. While so much space was devoted to the reporting of the bench and bar feud, the result in Wi Parata is relegated to a tiny paragraph near the end of the October 1877 Jurist edition. ${ }^{30} \mathrm{In}$ twenty-first century New Zealand, every law student studies Wi Parata while very few will have heard of George E Barton.

In late August, Prendergast, the head of the judiciary, took the assertive step of personally defending himself in a letter to the executive regarding Barton's petition to the legislature. ${ }^{31}$ In a recent case with some strong parallels, the New Zealand Supreme Court judge in question has, unlike Prendergast, defended himself through his lawyer in line with the convention that a judge will not publicly comment on a case, even one in which he or she is involved. ${ }^{32}$ In his letter, Prendergast dismissed the need for an inquiry on the basis that the allegations were untrue and even

New Zealand's history. In 1877 the prevailing statute was the Supreme Court Act 1862 which repealed ss 3 and 4 of the Supreme Court Judges Act 1858. Under the 1862 Act judges continued in office during good behaviour with provision for the Queen to remove a judge upon the address of both Houses of Parliament.

26 See for example reports in: the Evening Post (Wellington, 10, 21 and 23 August 1877); the West Coast Times (West Coast, 15, 18 and 30 August 1877); and the Grey River Argus (Greymouth, 15, 18 and 30 August 1877).

27 See Grant Morris "James Prendergast and the Treaty of Waitangi: Judicial Attitudes to the Treaty During the Latter Half of the Nineteenth Century" (2004) 35 VUWLR 117.

28 "Mr GE Barton's Petition" (1877) 2 NZ Jur (NS) 163 at 166.

29 "Mr Barton, Solicitor" West Coast Times (West Coast, 18 August 1877) at 2. Untitled (1877) 2 NZ Jur (NS) 195.

31 "Prendergast's reply to Barton's claims, 27 August 1877" Justice Department Records, J1 77/3361, ANZ.

32 "Judge to challenge conduct panel move" The Dominion Post (Wellington, 1 June 2010) at A5. 
if they were true they would not constitute grounds for removal. Prendergast's arguments to the Colonial Secretary were taken up by Parliament in its debate on the issue with Attorney General Frederick Whittaker supporting the Chief Justice. ${ }^{33}$ Swayed by its legal advisor, Parliament received, read and discharged the petition. ${ }^{34}$ During the parliamentary debates, Travers effectively advocated for the judges. ${ }^{35}$ Given his role in the Wellington bar's statement of support and his professional rivalry with Barton, it is not surprising that Travers was challenged in the House on the grounds of partiality. ${ }^{36}$ Despite his vehement defence, Travers' awkward position once again demonstrates that clear role boundaries did not exist in the 1870s New Zealand legal profession.

\section{$B$ Gillon v MacDonald and Prendergast's Contempt Ruling}

It is important to note that by this point Barton seemed absolutely committed to his cause of bringing about the dismissal of the Wellington Supreme Court bench. By January 1878 the relationship between Barton and the judges had broken down and was threatening to undermine the integrity and credibility of both the Wellington Supreme Court and the New Zealand Court of Appeal which sat in Wellington and was staffed by the New Zealand Supreme Court justices. Gillon $v$ MacDonald is one of New Zealand legal history's leading cases but unlike most other leading cases this is not due to its specific legal content. The events that occur in Gillon are of most importance to the extent that they directly relate to the feud in question.

Gillon, managing partner of the Evening Argus newspaper, was dismissed as editor of this periodical in $1877 .{ }^{37}$ One of the partnership agreement terms was that Gillon had the right to act as editor. Gillon brought an action to the Wellington Supreme Court stating that his partners were in breach of that agreement and asserting his right to act as editor. Barton acted for the plaintiff and William Travers and Frank Morton Ollivier for the defence. In the first hearing, in October 1877, Gillon's case was put to a jury which failed to agree on a verdict and was subsequently discharged. ${ }^{38}$

The matter was heard again on 16 January $1878 .{ }^{39}$ In the second hearing, the jury reached a verdict and found for Gillon. Gillon was still a partner and could continue to act as editor. This was a major victory for Barton and shows his ability as an advocate in a jury trial. While Barton's opinion of himself as the foremost barrister in New Zealand is open to debate, he was an articulate,

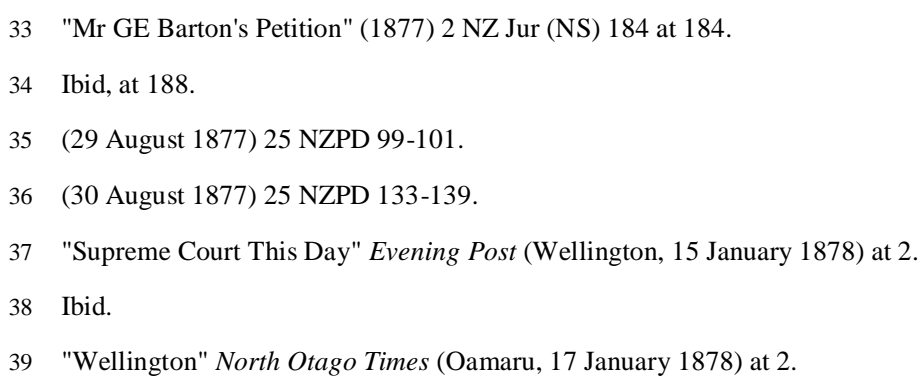


forceful and fearless courtroom lawyer. From the North Otago Times report, the victory seems a clear one and the fact that it ultimately became a hollow victory is in part due to the actions of Prendergast and Richmond.

On 19 January, Gillon, flush with victory, proceeded to the Evening Argus premises to exercise his rights. Ultimately Gillon wanted the business wound up and to receive his share of the wealth. One of his fellow partners, Kent, refused to allow Gillon to view the accounts. Gillon's partners refused to acknowledge his partnership rights. The result was a physical confrontation which led to Gillon being bodily removed from the offices. ${ }^{40}$ While not quite the 'Wild West', colonial Wellington had a rough and ready way in which to resolve disputes. Immediately following this fracas, Barton lodged a motion in the Supreme Court for an injunction to prevent the other partners from obstructing Gillon in exercising his rights as managing partner and editor of the Argus.

At a hearing on 30 January, this motion was denied by Prendergast and Richmond on two grounds. ${ }^{41}$ Firstly, Gillon acted improperly in not waiting for the court to grant relief in the form of a decree. Secondly, one of the Argus partners named Saunders was not named in the proceedings. It is easy to empathise with Barton. The first ground seems to undermine the jury's clear declaration in favour of Gillon. The second appears contrary to a fact supposedly established in the first hearing. Counsel for the defence, William Travers, is reported as admitting that Saunders was no longer a partner and that the jury did not need to make a finding on this issue. This became a contested issue as Richmond later claimed that Travers never made this admission. ${ }^{42}$

Barton was aghast at this turn of events which, in his mind at least, confirmed that the judges were carrying out a personal vendetta against him and his clients. He also lashed out at Ollivier and Travers, accusing them of "rascality". ${ }^{43}$ Prendergast and Richmond denied Gillon's application with costs. Barton refused to accept the judgment and continued to interrupt the judges stating that the court was mistaken and that he must be able to speak for his client. At this point, Prendergast finally lost his temper. The New Zealand Jurist captures the moment: ${ }^{44}$

[Prendergast:] Mr Barton, I have many times requested you to keep your seat and not to interrupt the proceedings of the Court, - notwithstanding such reiterated orders and rules you have continued interrupting the proceedings, and I therefore declare that unless you see fit to apologize to this Court and express regret for such transgressions, you will be adjudged guilty of contempt of court.

40 "Journalistic Fracas" Thames Star (Thames, 19 January 1878) at 2.

41 Gillon v MacDonald, above n 3, at 28.

42 "Letter from William Richmond to the Colonial Secretary regarding Barton's complaints, 3 October 1878" [1878] AJHR A6.

43 Gillon v MacDonald, above n 3, at 27.

44 Ibid, at 28. 
Mr. Barton replied that he had not the shadow of a doubt that the statement made that Gillon had no right to go on to the premises among his partners was utterly contrary to law. It was so monstrous that he could not help speaking on the subject as he did.

The Chief Justice: You are again interrupting the Court while it is delivering its judgment. I was very desirous indeed that you should have regretted your conduct.

Mr. Barton: This mode of procedure must end, it is perfectly clear. It must be stopped in some way. I know what the Court means, and I hope it knows what I mean.

The Chief Justice: The Court adjudges you guilty of contempt of court, and commits you to the public prison in Wellington for one month.

Prendergast had broken with usual judicial practice and imprisoned an advocate for contempt in face of the court, a strict liability criminal offence. Barton knew what to expect and almost dared Prendergast to take this extreme measure. It is important to note that in the Court of Appeal hearing of Spence v Pearson, immediately preceding Gillon v MacDonald, Barton accused the judges of partiality and was found in contempt of court and fined 50 pounds. ${ }^{45}$ Both Prendergast and Richmond briefly retired to agree upon this course of action. The case concerned the ability of Barton's client to appeal to the Privy Council and provides important context for what occurred soon after in Gillon. The charge and fine were subsequently dismissed when it became apparent that the Court of Appeal was sitting illegally. ${ }^{46}$ The court then 'transformed' into the Supreme Court to hear Gillon. Therefore, in the course of 1876 to 1878 , Barton was charged with contempt three times but only the Gillon charge was not revoked.

Was Prendergast's decision to imprison Barton inconsistent with English and colonial practice? As mentioned earlier, an historical examination of contempt is not the aim of this article but some interesting debates on this matter can be found in the New Zealand Jurist following the ruling. ${ }^{47}$ The Jurist notes that similarly extreme rulings relating to contempt were more common in small colonial courts such as in Sierra Leone and Hong Kong as compared to the English courts. Many of the cases cited resulted in the order for contempt being reversed or in a fine rather than imprisonment. ${ }^{48}$ The closest case on the facts to be found by the Jurist is from the Supreme Court of Sierra Leone in

45 Spence v Pearson (1878) 3 NZ Jur (NS) 25 (CA) at 26.

46 Ibid.

47 "Contempt of Court" (1878) 3 NZ Jur (NS) 16 at 16-18.

48 Smith $v$ The Justices of Sierra Leone (1841) 3 Moo 361 (PC); Smith $v$ The Justices of Sierra Leone (1848) 7 Moo 174 (PC); Rainy v The Justices of Sierra Leone (1852) 8 Moo 47 (PC); Ex parte Pater (1864) 5 B \& S 299; Re Pollard and the Chief Justice of Hong Kong (1868) 2 LR 106 (PC). 
which a lawyer was struck off for disrespectful demeanour in Court leading the Jurist commentator to note: 49

It is a painful reflection that we should be under the necessity of going to Sierra Leone - a colony of

negroes and 'mean whites' - in order to find a parallel for the proceedings of our own Court.

New Zealand judges during the period in question were generally reluctant to find counsel in contempt of court. Discussions of contempt frequently appear in the Jurist from 1876 to 1878 yet few New Zealand examples are provided. One example occurred in Barry v Gladstone Gold-Mining Company (1878). ${ }^{50}$ The case was heard in the Warden's Court at Macetown. The defendant's counsel, Finn, was held in contempt for interrupting proceedings and contradicting the judge. In a similar fashion to Barton, Finn challenged Warden Stratford to hold him in contempt, which the warden duly did. The bailiff arrested Finn but Stratford immediately allowed him the opportunity to apologise. Finn apologised and the contempt ruling was discharged. This case occurred in a relatively lowly setting but could lend weight to the argument that Prendergast should have offered Barton another opportunity to apologise after passing the sentence of imprisonment.

A recurring theme is that Prendergast's ruling was in stark contrast to the more liberal approach displayed by English judges. ${ }^{51}$ A particularly controversial issue in the New Zealand context was whether a judge could disbar counsel for contempt. In Re GE Barton (1876) Prendergast stated: ${ }^{52}$

For myself, I hope the authorities are as I believe them to be - I believe that they ought to be if they are not - that the deprivation of the power to act in a professional capacity with regard to barristers and solicitors, should be appropriate punishment for contempt, and not imprisonment or fine.

On 30 January 1878 Prendergast chose a fine and then imprisonment as the appropriate punishments. It is the decision to imprison Barton that ultimately made Gillon the cause celebre of this period.

Barton's prison sentence appears unprecedented, ${ }^{53}$ and raises questions about Prendergast's state of mind when making the ruling. It is probable that Prendergast lost his temper. If he had taken time to reflect he may have imposed a fine as he had attempted to do in Spence v Pearson. This would have been more in line with the decision in Re Pollard in which the Chief Justice of Hong Kong

49 "Contempt of Court", above n 47, at 17.

50 Case referred to in "Contempt of Court" (1878) 3 NZ Jur (NS) 39 at 40.

51 "More Contempt" (1877) 2 NZ Jur (NS) 193 at 194.

$52 \operatorname{Re}$ GE Barton (1876) 2 NZ Jur (NS) 13 at 16 (SC).

53 During the parliamentary debates relating to the 1878 Judicial Commission Bill, several Members of Parliament referred to the unique nature of the penalty, and in particular, the length of the prison sentence. See for example: Frederick Moss (30 September 1878) 29 NZPD 429. 
faced a similar situation. ${ }^{54}$ It can also be argued that Prendergast's decision risked undermining the right of counsel to defend clients to the best of their ability. If faced with imprisonment for mounting a vociferous defence, counsel may think twice before speaking up. By all accounts, the events in Gillon created a precedent in the British Empire though probably an unfortunate one. It should be noted that although Prendergast declared Barton in contempt in Gillon, his brother judge Richmond supported this decision in the hearing itself and during the events that followed.

In assessing whether Prendergast overreacted in his ruling it is useful to briefly note the law relating to contempt in the face of the court for advocates. This area of law has remained largely consistent and textbooks from past and present provide a useful guide. ${ }^{55}$ In criminal contempt proceedings the judge is able to proceed upon his own motion. ${ }^{56}$ This allows the judge to decide upon guilt and sentencing. These wide ranging powers granted to judges are justified due to the threat contempt poses to the administration of justice but judges should only ever use these powers sparingly. ${ }^{57}$ It is debatable whether Barton's actions constituted a clear threat to the administration of justice. If seen in the context of the previous clashes between bench and bar Barton's actions could well have posed a threat to the effective operation of the Wellington Supreme Court.

As pointed out at length in the Jurist, advocates should always be allowed great latitude to proffer arguments in support of clients and correct the court if the advocate believes an error has been made. ${ }^{58}$ In support of Barton's specific allegations of 30 January, it is established law that it is "proper for counsel to raise the matter of bias or lack of impartiality where there are reasonable

54 Re Pollard and the Chief Justice of Hong Kong (1868) 2 LR 106 (PC).

55 Recent textbooks provide a much superior summary of the law than contemporary textbooks and often provide historical context. Of the contemporary textbooks the following confirm the legality of Prendergast's actions though they are not particularly helpful in deciding whether his ruling could be seen as unreasonable in the circumstances: Henry John Stephen New Commentaries on the Laws of England (partly founded on Blackstone) (5th ed, Butterworths, London, 1863); Charles Johnston Edwards The Law of Execution upon Judgments and Orders of the Chancery and Queen's Bench divisions of the High Court of Justice (Stevens and Sons, London, 1888); Matthew Bacon A New Abridgment of the Law (T \& JW Johnson, Philadelphia, 1876); James Paterson Commentaries on the liberty of the subject and the laws of England relating to the security of the person (MacMillan, London, 1877); Charles Greenstreet Addison Wrongs and their remedies: being a treatise on the law of torts (5th ed, Stevens and Sons, London, 1879); Henry Coleman Folkard The Law of Slander and Libel: Founded upon the Treatise of the late Mr. Starkie (4th ed, Butterworths, London, 1876). Folkard's summary is the most useful in this case.

56 Gordon Borrie and Nigel Lowe Borrie and Lowe's Law of Contempt (2nd ed, Butterworths, London, 1983) at 321 .

57 David Eady and ATH Smith Arlidge, Eady and Smith on Contempt (3rd ed, Sweet and Maxwell, London, 2005) at 702 .

58 "Contempt of Court", above n 47, at 18. 
grounds for doing so even if the judge is not in fact biased". ${ }^{59}$ Given the many defeats that Barton experienced before Prendergast and Richmond, he obviously believed "reasonable grounds" existed for claiming personal bias towards him and his clients.

In terms of the specific 30 January Gillon hearing, Prendergast possibly did overreact but when considering the wider context and past history between bench and bar, Prendergast's actions can be justified. What is very clear is that Prendergast acted within his powers as a Supreme Court judge. While his decision to imprison Barton appears inconsistent with other jurisdictions it was still legal. On 12 and 30 September and 1 October 1878 the House of Representatives debated this issue, amongst others, in relation to the Judicial Commission Bill. MPs used case precedents and even legal textbooks to support their arguments. The two most convincing speeches were given by Attorney-General Robert Stout and former Attorney-General Frederick Whittaker. ${ }^{60}$ These two speeches provide a good summary of the law as it stood at 1878. Stout was adamant that: ${ }^{61}$

There can be no doubt as to the power of the Judges in England to commit persons for contempt. The

Supreme Court of New Zealand has all the power possessed by the superior Courts in England ...

Stout cited textbooks by William Blackstone and Thomas Starkie, ${ }^{62}$ and a number of cases, ${ }^{63}$ to support his claims. Despite Stout's belief that Barton's punishment was too severe, he voted against the Bill on the basis that the law was clear and that the judges had not committed misconduct that should lead to removal. Whittaker echoed Stout's view that the law was clear and quoted from Chief Justice Cockburn's decision in ex parte Goliffe (1872): ${ }^{64}$

It is very true that it is laid down by high authorities, and it is according to the reason of the thing, that every Court of record has power to fine and imprison for contempt committed in the face of the Court, while the Court is sitting in the administration of justice. Such a power is obviously necessary for the administration of public justice, which may be interrupted or obstructed unless there is a power to summarily repress such outrages.

59 Borrie and Lowe, above n 56, at 30 referring to Peter Butt "Contempt of Court in the legal profession" [1978] Crim LR 463 at 467.

60 Robert Stout was the Attorney-General under the Grey Ministry which lasted from 13 October 1877 to 8 October 1879. Frederick Whittaker was Attorney-General under the Atkinson Ministry which preceded it. Therefore Whittaker was Attorney-General during the first set of parliamentary debates relating to the feud while Stout was Attorney-General during the second set.

$61 \quad$ (30 September 1878) 29 NZPD 419.

62 No specific references are provided in the parliamentary debates but Stout could have been referring to the texts by Henry John Stephen (Blackstone) and Henry Coleman Folkard (Starkie) noted in above n 55. Blackstone's original text contains limited information on contempt.

63 Including Carus Wilson's case (1845) 115 ER 759 (QB); ex parte Fernandez (1861) 142 ER 349.

64 (30 September 1878) 29 NZPD 439 
Several of the Bill's supporters went to great lengths to prove that Barton's committal was unique and excessive while the Bill's opponents provided several examples in rebuttal. ${ }^{65}$ On the issue of whether Prendergast possessed the power to commit, the Bill's opponents emphatically won the argument.

Unsurprisingly, Barton appealed the contempt ruling and in Re George Elliot Barton on 29 March 1878, Richmond ruled that Prendergast indeed possessed the power to commit a barrister instantly to prison for contempt of court. ${ }^{66}$ This was well established law. Barton should have known this and focused solely on whether the particular circumstances justified the ruling rather than whether the ruling was within the judge's powers or whether the correct process was followed by the judges. Despite this, justice should not only be done but also be seen to be done. Having Richmond decide upon Prendergast's ruling is a clear conflict of interests given that Barton had been officially complaining about the behaviour of both judges. Despite there being only two judges in Wellington this matter could have probably waited for the arrival of another Supreme Court judge which would have occurred at the next sitting of the full Court of Appeal.

Barton received support for his cause from the Dunedin and Christchurch Bars and a meeting of Wellington citizens. ${ }^{67}$ In written statements these groups supported the possibility of an inquiry, placing Prendergast and Richmond in an embarrassing position. It is telling that no resolutions were passed by the Auckland or Wellington Bars. Prendergast, though originally a Dunedin barrister, had focused his energies on Wellington for over a decade since moving permanently to the capital city in 1867.

In the New Zealand Jurist (February 1878), the editor George B Barton, an ally of George E Barton, attacked Prendergast. ${ }^{6}$ While he did not speak for the New Zealand legal profession, his journal was circulated throughout the colony. It is important to note that much of the reporting of the feud is to be found in GB Barton's publication raising questions of bias against the judges: ${ }^{69}$

Whatever there may be to regret in Mr. Barton's demeanour in this case, it must be admitted that there is still more to be regretted in the action of the Bench ... no one who will read the [Gillon] report can fail to be struck with the utter want of proportion between the offence and the punishment; nor can anyone fail to see that such a mistake is fatal to the reputation of a Judge.

65 Whittaker argues that there are a number of examples of English lawyers being punished for contempt and that he has observed committals for contempt. It is important to note that he does not provide a specific example of where a lawyer has been committed for contempt. (30 September 1878) 29 NZPD 440.

66 Re George Elliot Barton (1878) 3 NZ Jur (NS) 67 (SC).

67 New Zealand Mail (Wellington, 29 June 1878) at 9-10.

68 "Contempt of Court" (1878) 3 NZ Jur (NS) 16 at 16-18.

69 Ibid, at 17. 
While serving his prison term, Barton stood for, and won, the election for Wellington Central. ${ }^{70}$ The campaign was organised by his son, L'Estrange Barton and Gillon loyally spoke on his behalf at rallies. ${ }^{71}$ Barton supported George Grey's 'liberal party' placing him politically in opposition to Prendergast and Richmond, who personally leaned towards 'conservatives' such as Harry Atkinson. ${ }^{72}$ Ironically, Barton replaced William Travers, who had chosen not to stand again for the high-profile electorate. This vote of confidence in George Barton can be seen as a popular vindication of the outspoken lawyer and a rejection of Prendergast's contempt ruling. To his dismay, Barton did not receive the same vindication from New Zealand's power brokers, most of whom supported the judges.

Gillon v MacDonald did not end with Barton's imprisonment. More hearings ensued, all of which confirmed Barton's failure to obtain a suitable remedy for his client. Upon Barton's release, he made an application to hold Gillon's partners in contempt of court for selling the Argus and Gillon's shares in the Argus while the matter was before the court. ${ }^{73}$ At the hearing on 12 April 1878, Richmond noted that the defendants' actions were improper but unlike the third hearing, the bench refused to rule contempt of court as no court order had been breached. ${ }^{74}$ Barton then proceeded to argue that the suit's subject matter had now disappeared and therefore the court should provide a remedy for Gillon. Upon this matter Richmond reserved judgment.

In the 12 April hearing, Barton gamely attempted to gain a reversal of the judges' 30 January refusal to grant an injunction. ${ }^{75}$ Barton had never accepted the court's decision and importantly it was the 30 January hearing during which he was adjudged in contempt of court. This unrepentant attitude did not impress Richmond, who rejected Barton's motion and pointed out that an injunction would be irrelevant now that the property in dispute had been sold. The 4 June hearing is formally reported in the Jurist and concerns Barton's notice of motion for decree. ${ }^{76}$ The notice was to be heard on 25 May and while the defendant's counsel Ollivier was present, Barton was not. The matter was postponed until 4 June when once again, Barton was absent. Prendergast struck the case off the list due to Barton's failure to support the motion though he refused Ollivier's request to have the matter absolutely dismissed. Prendergast then awarded costs to Ollivier for his two appearances in court to defend the motion.

70 "The case of Mr Barton" Evening Post (Wellington, 19 February 1878) at 2.

71 "The Nomination" Evening Post (Wellington, 16 February 1878) at 2.

72 Morris, above n 6.

73 "Supreme Court Sittings in Banco This Day" Evening Post (Wellington, 9 April 1878) at 2.

74 "Supreme Court Sittings in Banco This Day" Evening Post (Wellington, 12 April 1878) at 2.

75 Ibid.

76 Gillon v MacDonald (1878) 3 NZ Jur (NS) 137 (SC). 
In a final hearing on 21 August, Richmond belatedly delivered judgment for the plaintiff on the motion for decree and also declared the partnership dissolved from the commencement of the suit. ${ }^{77}$ Richmond added the caveat that if Saunders was found to be a partner then Gillon would need to undertake a new action. By this time, Gillon had been declared bankrupt and his shares in the Argus had been sold. ${ }^{78}$ Richmond suggested that the matter of the accounts be decided in chambers if the parties could not agree but at this stage the matter had, to a large extent, become redundant. Despite this final judgment, events had overtaken the court's ruling and Gillon had failed in his battle with his partners. Barton used the outcome to strengthen his appeal to the Colonial Secretary later that year: ${ }^{79}$

Judge Richmond's misconduct in corruptly sheltering Gillon's opponents and refusing protection to Gillon, while those opponents were 'spiriting away' the whole property of the subject-matter of the litigation, thus converting that litigation into a 'hollow mockery,' and the decree, when he afterwards made it, into a 'Dead Sea apple.'

\section{The Events Following Gillon}

The Gillon case dragged on throughout 1878 and provided a legal forum for a feud which was also being played out in a political forum, namely, the New Zealand Parliament. On his release from prison, Barton once more petitioned the government for an inquiry into the behaviour of Prendergast and Richmond. In the first instance, Barton approached a minister in the presiding Grey Government, John Ballance. Ballance correctly noted that it is the legislature's role to ultimately decide on whether a judge should be removed from office ${ }^{80}$ though Barton was also correct in stating that the executive should play a role in initiating this process. In any event, Barton was now part of the legislature and could affect proceedings from within the House of Representatives. Following the defeat of the Judicial Commission Bill, Barton launched tirades against Prendergast and Richmond under the shield of parliamentary privilege. ${ }^{81}$ Richmond was even forced to submit a letter to the House of Representatives pointing out inaccuracies in Barton's claims. ${ }^{82}$ While the feud began with a focus on Prendergast's actions, it ended with Richmond taking the lead in the struggle against Barton. This is due to Richmond taking the leading judicial role in the post-January 1878

77 "Supreme Court Sittings in Banco This Day" Evening Post (Wellington, 21 August 1878) at 2.

78 "Wellington This Day" Thames Star (Thames, 20 August 1878) at 2.

79 "Letter from Barton to Whitmore, 16 December 1878" [1879] AJHR A4 at 32.

80 "Mr Barton and the Judges" New Zealand Mail (Wellington, 29 June 1878) at 9-10.

81 "Mr Barton and the Judges" Timaru Herald (Timaru, 5 November 1878) at 8. Also found in (18 October 1878) 30 NZPD 914-921.

82 "Letter from William Richmond to the Colonial Secretary regarding Barton's complaints, 3 October 1878" [1878] AJHR A6; New Zealand Mail (Wellington, 12 October 1878) at 12-13. 
Gillon hearings and also Richmond's October 1878 letter defending himself against Barton's accusations.

The contestability of early law reports, and in particular the New Zealand Jurist, is illustrated by the letter submitted by Richmond on 3 October 1878 to the House of Representatives outlining misstatements of fact in Barton's allegations. ${ }^{83}$ Richmond also questioned the trustworthiness of the Jurist reporting of the Gillon proceedings. Part of this complaint is based on the claim that the Jurist largely follows the trial report appearing in the New Zealand Times newspaper. That a law report would rely on a newspaper is of credit to the newspaper but raises questions about the credibility of the law report. As Richmond argues in his letter: ${ }^{84}$

\footnotetext{
It does not appear to have occurred to any one who relied upon the report in the Jurist to inquire into the origin of that report. I declare it to be quite untrustworthy, so far as it is original. I have reason to believe that it was not furnished to the Jurist by either of the barristers who are announced as the reporters for this district. The report in the New Zealand Times of $31^{\text {st }}$ January is a fair report so far as it goes; but it fails, as almost any report must do, to convey an adequate idea of the scene in Court. It also fails, or rather it does not attempt, to show the nature of the questions before the Court. Without some apprehension of these questions it is not possible for any one to understand how thoroughly without ground of complaint Mr. Barton has been.
}

The limitations of law reporting are made clear in Richmond's letter but more importantly the credibility of the New Zealand Jurist is attacked. To state that the Gillon report is "untrustworthy" calls into question the general quality of reporting in the Jurist. To what extent could lawyers and judges rely on its accuracy when researching and applying relevant case law? Richmond also insinuated that Barton used his close relationship with the Jurist editor to influence the wording of the report. ${ }^{85}$ Barton countered Richmond's claims in Parliament stating that the Jurist report was fair and accurate. ${ }^{86}$

In August 1878, MP Cecil Albert De Lautour introduced the Judicial Commission Bill into Parliament. ${ }^{87}$ The Bill aimed to set up a commission of inquiry to investigate Barton's imprisonment

83 "Letter from William Richmond to the Colonial Secretary regarding Barton's complaints, 3 October 1878" [1878] AJHR A6.

84 Ibid.

85 Ibid.

86 "Mr GE Barton's Case" (1878) 3 NZ Jur (NS) 139 at 139. Also found in (18 October 1878) 30 NZPD 918. The judges' notebooks of Richmond and Prendergast are located in Archives New Zealand and contain references to a number of the cases mentioned in this article, including Gillon v MacDonald, above $\mathrm{n}$ 3. The Gillon references do not include further important details, that is, they reflect what can be found in the case reports.

87 A good discussion of this Bill is found in "Mr Barton and the Judges" Timaru Herald (Timaru, 5 November 1878 ) at 8 . The introduction of the Bill is found in (12 September 1878) 29 NZPD 135. 
for contempt, the power of judges to rule in this way and the role of Parliament in controlling judicial misbehaviour. ${ }^{88}$ The judicial prerogative relating to contempt has been enshrined in English common law for several centuries. As mentioned earlier, leading MPs with legal backgrounds, including Robert Stout and Frederick Whittaker, made this point in the ensuing parliamentary debate. ${ }^{89}$ It is unlikely that any investigation following from De Lautour's Bill would have advocated overturning the law, however Parliament could still potentially find Prendergast's ruling unjust in the specific circumstances. MP for Parnell, Frederick Moss, who served on the Otago Provincial Council during Prendergast and Barton's time in Dunedin, spoke in support of Barton arguing that Prendergast's response was an overreaction. ${ }^{90}$ As with its previous debate on this matter, Parliament voted down the Bill and declined to initiate Barton's much anticipated inquiry.

The debates relating to the Judicial Commission Bill can be found in the New Zealand Parliamentary Debates and provide fascinating insights into different aspects of the feud and touch upon many of the constitutional issues raised in this article. To a large extent the MPs reflected the arguments and legal precedents found in the Jurist and newspaper reports ${ }^{91}$ rather than furnishing new evidence to support their arguments. The partisan nature of the House is also revealed through the debates. After Barton's stinging parliamentary attack upon the judges on 18 October 1878, other MPs lined up to reply either in support of Barton or to show their disgust at the vicious attack. ${ }^{92}$

Consistent with his behaviour throughout this saga, Barton refused to let the matter rest after the defeat in the House of Representatives. With the legislature route blocked he again targeted the executive in the form of Colonial Secretary Whitmore. ${ }^{93}$ Whitmore rejected Barton's claims as lacking specificity and asked for clarification. ${ }^{94}$ Barton's clarifications, which do seem to answer Whitmore's queries, were also rejected as lacking specificity. ${ }^{95}$ It seems Whitmore was set on

88 Judicial Commission Bill as found in (1878) 3 NZ Jur (NS) 112

89 "Parliament: House of Representatives: Yesterday" Evening Post (Wellington, 1 October 1878) at 2.

90 Ibid; In 1897, Prendergast travelled to the Cook Islands to investigate Moss' actions as British Resident, eventually exonerating him, Morris, above n 6, at 186

91 For the most part, newspaper editorial comment relating to the feud was restrained and often descriptive but as demonstrated in "Mr Barton and the Judges" Timaru Herald (Timaru, 5 November 1878) at 8, editorial support for Barton had begun to wane by the later stages of the saga, "It surely will never be permitted that a member of Parliament shall slander the highest judicial officers in the country with impunity. Every consideration of justice and expediency alike demands that, as, if the charges are proved, the Judges must quit the Bench, so, if they are not proved, Mr Barton must quit both the House and the Bar."

93 "Letter from Barton to Whitmore, 26 October 1878" [1879] AJHR A4 at 1. 
denying Barton his inquiry. Barton made the fair assertion that Whitmore had effectively ignored his charges and then, true to form, rashly accused him of allowing Richmond to ghost-write his previous reply despite it being signed by Whitmore. ${ }^{96}$ This was one step too far. The New Zealand government in the form of one of its most powerful ministers, made it very clear to Barton that the matter was now at its natural conclusion. ${ }^{97}$ At this point Barton finally accepted defeat and made no more attempts to force an inquiry.

It is unclear to what extent Prendergast and Richmond had personal support amongst the Grey Ministry. Whitmore was a Prendergast ally from the 1860s and Richmond was a highly respected former government minister, but Barton claimed Grey and Stout were in support of his claims. ${ }^{98}$ This seems unlikely given that the government refused to assist Barton in his attempts to initiate an inquiry. It should be noted that the Grey Ministry did not make any concerted efforts to defend the judges though possibly due to respect for the separation of powers rather than any antipathy towards Prendergast and Richmond. Given the outcome of the saga, Barton was most probably seen as a thorn in the side of the Grey Ministry rather than an asset to be supported.

Barton lost his parliamentary seat in 1879 and left New Zealand soon after, his legal and political careers in ruins and ostracised from the establishment. His brief return as a Native Land Court judge in 1888 lasted only two years before he resigned following a bitter feud with a fellow judge. He then left New Zealand permanently and died in Paris in 1903. ${ }^{99}$

\section{INSIGHTS INTO THE NATURE OF THE NEW ZEALAND LEGAL PROFESSION}

The central argument of this article is that Gillon provides excellent insights into the nature of the New Zealand legal profession and therefore should be seen as a leading case. Few other cases in New Zealand's legal history so vividly reveal the tension between bench and bar. Parallels can be drawn to modern times, most obviously in the recent inquiry into the actions of Supreme Court Justice Bill Wilson in deciding a 2007 Court of Appeal case which involved a lawyer with whom Wilson had a close business relationship. ${ }^{100}$ While the Wilson case has captured headlines, the

96 "Letter from Barton to Whitmore, 16 December 1878" [1879] AJHR A4 at 33.

97 "Letter from Whitmore to Barton, 20 December 1878" [1879] AJHR A4 at 34.

98 "Letter from Barton to Whitmore, 16 December 1878" [1879] AJHR A4 at 32. As mentioned above, Stout voted against the Judicial Commission Bill. Grey voted for the Bill and launched a vociferous defence of Barton during the parliamentary debates, (1 October 1878) 29 NZPD 458.

99 "Barton, George Elliott" in GH Scholefield (ed) Dictionary of New Zealand Biography (Wellington: Department of Internal Affairs, 1940) at 46.

100 "Judge to challenge conduct panel move" The Dominion Post (Wellington, 1 June 2010) at A5 and "Top Judge quits with a year's pay plus costs" The Dominion Post (Wellington, 22 October 2010) at A5. The alleged misconduct revolved around whether Justice Wilson properly disclosed information about this relationship. Justice Wilson's argument that the process should cease because the alleged misconduct could 
vitriol and scandal associated with the Gillon saga renders the coverage of the modern example tame in comparison.

Much has been made of the homogenous and tight-knit New Zealand legal fraternity of the past. It is often concluded that this led to an 'old boys' network' in which male lawyers closed ranks to protect the interests of the profession against outsiders. A ready example is the shameful way in which New Zealand's first female lawyer, Ethel Benjamin, was ostracised by the Otago legal profession after her admission in 1897. ${ }^{101}$ A small group with shared histories also has the potential to act in the opposite fashion. Closely linked careers and a limited amount of suitable applicants for top positions can easily lead to the rivalry and internecine warfare that occurred in the Wellington feud. The Wellington legal profession of the late 1870s was tiny and insular and to have three of its leading lights in constant battle would have affected every practitioner in some way. As can be seen throughout this article, professional and personal links affected the nature and outcome of the feud.

The New Zealand legal profession could not close ranks in this instance as the dispute was very much within its ranks. Barton and Travers were the most experienced lawyers at the Wellington bar. ${ }^{102}$ In terms of experience, they were the peers of Richmond and Prendergast and if the judicial selection process had turned out differently it could just as easily have been Prendergast appearing before Barton in the Wellington Supreme Court.

Ultimately, enough of the profession, including lawyers in Parliament, sided with the judges to protect them against Barton's campaign for dismissal. The rank and file of the profession split but the legal power brokers were clearly aware of the potential for disaster if Barton was successful in launching an official inquiry. Prendergast and Richmond may have expected more vocal support from the establishment but they received enough tacit support to remain in office. Post-1878 their careers flourished while Barton's disintegrated. Barton's failure demonstrates the challenges involved in directly confronting established power. This is a constant throughout history and Barton's inflammatory approach backfired as he eventually alienated most of his powerful supporters.

The reputation of the New Zealand legal profession was undermined significantly by the Gillon saga. The competence of two leadings judges, including the Chief Justice, was questioned by

not justify removal even if proved, echoes Prendergast's argument in his letter to the Colonial Secretary, "Prendergast's reply to Barton's claims, 27 August 1877", above n 31.

101 Janet November In the footsteps of Ethel Benjamin: New Zealand's first woman lawyer (Victoria University Press, Wellington, 2009).

102 In early 1877, Barton argued for a system of seniority to be implemented in New Zealand but was rebuffed. However it was agreed that either Barton or Travers would rank first at the New Zealand bar if a system was put in place. See "Seniority at the bar" (1877) 2 NZ Jur (NS) 89. 
lawyers, politicians and the media. ${ }^{103}$ Leading figures at the Wellington Bar accused each other of deception and the career of an outstanding courtroom advocate was irredeemably damaged. The unfortunate affair also illustrates the chaos that can be caused by a renegade, populist barrister. That the situation should have been allowed to progress so far is a poor reflection on Prendergast's leadership skills in his early years as Chief Justice. This damage to Prendergast's reputation could have been one of Barton's key aims. Calls for judicial dismissal are among the most controversial actions that can be taken, especially within the legal profession as it goes to the heart of the relationship between bench and bar. The trust and mutual respect required from both parties is vital to the effective functioning of the courts and to the successful implementation of the rule of law. Judges rely on advocates to act as responsible officers of the court while advocates rely on judges to adjudicate in an impartial fashion.

This example also raises interesting issues relating to the separation of powers. Barton would argue that the legislature twice abrogated its role in failing to launch an inquiry. In rebuttal it could be argued that if there ever was a legislature to unseat the reactionaries, Richmond and Prendergast, it was the liberal-led legislature of the late 1870 s and by choosing not to, it clearly indicated that no inquiry was necessary. The legislature chose not to act and the executive rightly refused to usurp the legislature's power.

Intriguingly, this feud could also have affected New Zealand's most infamous legal decision. After analysing the Gillon feud one is forced to read the Wi Parata judgment in a different light and pay closer attention to its main actors. If there is even a sliver of truth in Barton's accusation that Prendergast and Richmond showed bias towards his clients on account of the feud, then the dismissive treatment of Wi Parata's claim could have partly resulted from the feud.

\section{CONCLUSION}

The controversy surrounding the Wellington Supreme Court from 1876 to 1878 reaches its climax in the case of Gillon $v$ MacDonald. Gillon is the vehicle for a feud that split the New Zealand legal profession and undermined the authority of the Wellington based judiciary. While not important for its specific subject matter, Gillon contains one of the most startling episodes of contempt of court by a barrister in New Zealand's legal history. As the case took place over several months, the bitter feud between bench and bar developed and transformed as the case proceeded. The feud had a ripple effect. Firstly, it affected the parties involved in the Gillon case including the plaintiff, the lawyers and the judges. It also affected Barton's clients, including possibly Wi Parata in his bid to gain judicial recognition of native title. The three branches of government were all dragged into the conflict though the legislature and executive avoided launching an inquiry into the matter, despite Barton's best efforts.

103 See for example "Contempt of Court", above n 47, at 17; "Parliament: House of Representatives: Yesterday" Evening Post (Wellington, 1 October 1878) at 2. 
Both parties in the feud must share some blame for the damage wrought, but Barton's bloodymindedness is at the heart of events. Time after time, Barton refuses to compromise in any way and demonstrates an Ahab-like monomania in attempting to remove the judges from the bench. Driven by resentment and personal animosity, the rivalries in the fledgling New Zealand legal profession are laid bare in this case. Prendergast's decision to imprison Barton was possibly rash and definitely back-fired, yet it should be remembered that the Chief Justice was attempting to use the tools at his disposal to protect the authority of the Supreme Court, an authority that Barton failed to respect. This fact was quietly accepted by most other power brokers of the time, including Crown Ministers. To see this as merely a closing of ranks by the elite fails to acknowledge Barton's leading position at the New Zealand bar and the support he received from powerful sources. The end result was defeat for both Barton and his client Gillon.

The Gillon saga is an unflattering portrayal of the New Zealand legal profession and unfortunately serves to confirm some of the prejudiced insults levelled at colonial courts by the English legal establishment. Frederick Moss stated that "this case has lowered our Supreme Court in the eyes of thousands of people in the colony". ${ }^{104}$ There were no winners in the Gillon saga and the biggest casualty was the reputation of the New Zealand legal profession.

104 (30 September 1878) 29 NZPD 431 